\title{
Clinical and Therapeutic Implications of Follistatin in Solid Tumours
}

\author{
LEI SHI ${ }^{1,2}$, JEYNA RESAUL ${ }^{2}$, SIONED OWEN ${ }^{2}$, LIN YE $^{2}$ and WEN G. JIANG ${ }^{2}$ \\ ${ }^{1}$ Urology Department, Yantai Yu Huang Ding Hospital, Yantai, Shandong Province, P.R. China; \\ ${ }^{2}$ Cardiff China Medical Research Collaborative, Division of Cancer and Genetics, \\ Cardiff University School of Medicine, Cardiff, U.K.
}

\begin{abstract}
Follistatin (FST), as a single-chain glycosylated protein, has two major isoforms, FST288 and FST315. The FST315 isoform is the predominant form whilst the FST288 variant accounts for less than 5\% of the encoded mRNA. FST is differentially expressed in human tissues and aberrant expression has been observed in a variety of solid tumours, including gonadal, gastric and lung cancer, hepatocellular carcinoma, basal cell carcinoma and melanoma. Based on the current evidence, FST is an antagonist of transforming growth factor beta family members, such as activin and bone morphogenetic proteins (BMPS). FST plays a role in tumourigenesis, metastasis and angiogenesis of solid tumours through its interaction with activin and BMPs, thus resulting in pathophysiological function. In terms of diagnosis, prognosis and therapy, FST has shown strong promise. Through a better understanding of its biological functions, potential clinical applications may yet emerge.
\end{abstract}

Follistatin (FST), which was first isolated from porcine and bovine follicular fluid $(1,2)$, was initially described as a protein involved in the regulation of the secretion of folliclestimulating hormone. This monomeric glycosylated polypeptide chain is encoded by a single gene located on the long arm chromosome 5q11.2 (3), which through alternative splicing may be transcribed into the mRNA precursors, FST317 and FST344. From these precursors, three major FST isoforms may be produced, namely FST288 (from preFST317), FST315 (from pre-FST344) and a third FST

Correspondence to: Professor Wen G. Jiang, Cardiff China Medical Research Collaborative, Division of Cancer and Genetics, Cardiff University School of Medicine, Cardiff, CF14 4XN, U.K. Tel: +44 2920687865, e-mail: JiangW@cf.ac.uk

Key Words: Follistatin, activin, bone morphogenic protein, cancer, review. isoform, FST303, produced from the post-translational truncation of the FST315 $C$-terminus. These three main FST isoforms can also be glycosylated to yield six further FST isoforms that were previously identified in bovine (4) and porcine $(5,6)$ follicular fluid. At the core, all FST isoforms contain a 63 residue $N$-terminal domain and three follistatin domains, termed FSD1, FSD2 and FSD3. These domains comprise 73-77 amino acid residues and are characterised by an arrangement of 10 conserved cysteine residues (7). Both FST288 and FST315 are differentially expressed in human tissues (6-9). FST315 is the predominant isoform, whilst the FST288 isoform accounts for less than $5 \%$ of the encoded mRNA $(10,11)$. Some molecules such as activin, transforming growth factor-beta (TGF $\beta)$, forkhead domain transcription factor L2 (12, 13), gonadotropin-releasing hormone (14), zinc finger protein (GLI2) (15), dexamethasone (16), androgens (17), activators of winglessrelated integration site (WNT) signalling $(18,19)$ and $1,25-$ dihydroxyvitamin D (20) have been shown to regulate the transcription of the FST gene. In addition, down-regulation of FST gene expression by peroxisome proliferator-activated receptor gamma $(\operatorname{PPAR} \gamma)$ or the transcription factor epiprofin $(21,22)$ has been shown.

As an antagonist of TGF $\beta$ superfamily member activin, FST seems to primarily function in relation to the role that activin plays. Along with FST, activin acts as a pleiotropic growth factor system, which is involved in proliferation, differentiation, and apoptosis of a number of cell types (2328). As such, the functions of the FST isoforms are therefore linked to their binding affinity for activin $(6,10$, 11, 29-37). In fact, this critical binding and neutralisation of activin, either partial or complete, is based on the order of at least two of the FST cysteine domains and its $\mathrm{N}$ terminal (38), conferring a difference in affinities for activin between the FST isoforms. The binding complex between activin and FST generally occurs in a 1:2 ratio, where the two FST molecules, connected $C$-terminus to $N$ - 
terminus, envelop the activin molecule, thus blocking access to both the type I and type II receptor binding sites (9). The binding complex handicaps the interaction of activin with its specific receptors, leading to the inhibition of most of its the biological effects in various cells and tissues $(5,6,11,32,35)$. An important contribution of the FSD1 region to FST localisation and hence, bioactivity, lies in its ability to bind to plasma membrane heparin sulfate proteoglycans. For example, FST288 binds to heparin sulfate proteoglycans with a high affinity and may function as a local regulator by potentially preventing the autocrine, endocrine and paracrine actions of activin (39). Additionally, FST288-activin binding complex can interact with cell-surface proteoglycans followed by the internalization and subsequent degradation of this complex with lysosomal enzymes $(3,5,6)$. Conversely, FST315 is predominantly localised in the circulation, consistent by its low binding affinity for heparin, and its binding to activin appears to be irreversible (5).

Activin seems to be able to exert context-dependent and cell type-specific inhibiting and activating functions (40). There is evidence that activin can both have an inhibitory or proliferative effect on cell proliferation; dependent on the cell type (41-47). In vivo studies have shown that FST knockout mice died soon after birth due to a variety of skeletal and cutaneous defects amongst other defects seen in the activin-deficient mice (48). Lin et al. also demonstrated that mice with an FST315-expressing construct could overcome this neonatal lethality but still had severe biological defects. Overexpression of mouse FST using the mouse metallothionein I promoter in transgenic mice led to gonadal defects and eventual infertility, primarily due to local effects of FST in these tissues (50). Dermatological defects were present in both FST-knockout and -overexpressing mice, but there was no evidence of cancer (51). Some of these defects were similar to those that were seen in bone morphogenetic protein 5 (Bmp5)-mutant mice (52) and TGF $\beta$ overexpressing mice (53). These similarities suggested that FST might be a modulator of other TGF $\beta$-related proteins apart from activin or might function independently (48). Some other studies have demonstrated that FST may also bind to other molecules such as BMPs, especially BMP-2, $-4,-5,-6,-7$ and $-11(4,54-58)$, myostatin (59) and TGFß3 (60). Table I shows the expression profile of FST and its targeting ligands in various tissues and organs of the human body. In addition, FST may also have an interaction with other non-TGF $\beta$ family proteins, such as angiogenin, known as a pro-angiogenic factor (61), and $\alpha 2$ macroglobulin, known as a serum pan-protease inhibitor (62). However, further investigations are required to explain the functional value of the interplay between FST and these molecules.

\section{Follistatin in the Development and Progression of Solid Tumours}

A study on the molecular mechanisms underlying antral gastric tumours, which develop in gastrin-deficient mice, demonstrated elevated FST expression in the proliferative neck zone of hyperplastic antrum, a trend which has also been observed in human gastric cancer (63). These findings indicated that antral hyperplasia in gastrin-deficient mice involves amplification of mucous cell lineages, in which FST may play a role. In addition, strong FST expression was found in basal cell carcinoma and seemed to be mainly activated by transcription factor GLI2, which as a Hedgehog signalling mediator, has been shown to be up-regulated by the expression of FST $(15,64)$. This phenomenon is suggestive of the engagement of FST in the development of basal cell carcinoma, which has yet to be fully elucidated.

Stove et al. found that all melanoma cell lines expressed activin receptors. Treatment of these cell lines with activin also resulted in the phosphorylation of SMAD signal transduction molecules (65). Secretion of FST, either native or after retroviral transduction, efficiently prevented SMAD activation or activation of an activin-responsive luciferase reporter construct. In melanocytes, activin treatment led to growth inhibition and induction of apoptosis, processes which were counteracted by an addition of FST. Thus this study suggests that in melanoma, FST is involved in neutralising the effects of activin.

Activin also appears to be a major regulatory factor in liver tissue homeostasis, controlling cell proliferation and apoptosis. Both activin and TGF $\beta$ itself may inhibit DNA synthesis and induce apoptosis in vitro as well as in vivo (6672). It has been reported that experimentally administered FST acted as an inducer of hepatocellular DNA synthesis (73-76) through reduction in the local bioavailability of activin. Additionally, overexpression of FST was also found in rodent liver tumours (77), of which most were hepatocellular carcinomas, when compared to surrounding liver tissue; the level of overexpression of FST was different but independent of the carcinogen treatment that rodents had received and the histological stage of malignancy. Differential expression of FST and its interacting ligands in different malignancies is shown in Table II.

In addition, there is also some indirect proof regarding the growth-promoting effect of FST on prostate cancer cells. Rapamycin (78) and soy isoflavones (79), plant-derived polyphenolic compounds with estrogen-like properties, inhibit prostate cancer cell growth and are associated with a decrease in the expression of FST. Type III TGF $\beta$ receptor has been reported to play an inhibitory role in the growth of prostate cancer cells (80). FST has been shown to directly bind to and completely block type III TGF $\beta$ receptor-induced epithelialmesenchymal transition of normal murine mammary gland 
Table I. Expression profile of follistatin (FST) and its target molecules in different organs and tissues.

\begin{tabular}{|c|c|c|c|c|c|c|c|c|c|c|c|c|}
\hline Tissue & FST & INHA & INHBA & INHBB & BMP2 & BMP4 & BMP5 & BMP6 & BMP7 & BMP11 & Myostatin & TGF $\beta 3$ \\
\hline Adipose tissue & 0 & 0 & 0 & 0 & 0 & 77 & 0 & 0 & 0 & 0 & 0 & 77 \\
\hline Adrenal gland & 30 & 0 & 0 & 30 & 0 & 0 & 0 & 0 & 0 & 30 & 0 & 0 \\
\hline Ascites & 0 & 0 & 0 & 0 & 0 & 0 & 0 & 0 & 0 & 0 & 0 & 0 \\
\hline Bladder & 0 & 0 & 0 & 0 & 0 & 0 & 0 & 0 & 0 & 0 & 0 & 0 \\
\hline Blood & 0 & 0 & 24 & 0 & 0 & 0 & 0 & 98 & 0 & 16 & 0 & 0 \\
\hline Bone & 83 & 0 & 55 & 0 & 27 & 97 & 0 & 0 & 13 & 55 & 0 & 41 \\
\hline Bone marrow & 41 & 0 & 20 & 0 & 0 & 0 & 0 & 0 & 0 & 0 & 0 & 41 \\
\hline Brain & 2 & 9 & 2 & 5 & 4 & 7 & 2 & 8 & 43 & 23 & 1 & 13 \\
\hline Cervix & 0 & 0 & 0 & 0 & 247 & 0 & 0 & 61 & 0 & 0 & 0 & 0 \\
\hline Connective tissue & 87 & 0 & 26 & 0 & 26 & 13 & 13 & 6 & 33 & 13 & 6 & 20 \\
\hline Ear & 248 & 0 & 0 & 0 & 0 & 0 & 0 & 0 & 0 & 0 & 0 & 0 \\
\hline Embryonic tissue & 42 & 0 & 42 & 0 & 14 & 108 & 37 & 9 & 32 & 9 & 0 & 14 \\
\hline Oesophagus & 0 & 0 & 49 & 0 & 0 & 0 & 0 & 0 & 0 & 0 & 0 & 49 \\
\hline Eye & 47 & 19 & 47 & 33 & 43 & 43 & 9 & 14 & 86 & 129 & 4 & 33 \\
\hline Heart & 11 & 0 & 0 & 22 & 44 & 11 & 100 & 0 & 100 & 22 & 11 & 78 \\
\hline Intestine & 12 & 0 & 38 & 8 & 17 & 219 & 4 & 21 & 30 & 25 & 0 & 8 \\
\hline Kidney & 14 & 0 & 4 & 4 & 4 & 4 & 0 & 9 & 42 & 4 & 0 & 18 \\
\hline Larynx & 127 & 0 & 85 & 0 & 426 & 0 & 0 & 42 & 0 & 0 & 0 & 0 \\
\hline Liver & 24 & 9 & 4 & 9 & 9 & 63 & 9 & 0 & 0 & 14 & 0 & 9 \\
\hline Lung & 41 & 2 & 23 & 20 & 29 & 14 & 11 & 20 & 5 & 11 & 11 & 23 \\
\hline Lymph & 0 & 0 & 0 & 0 & 0 & 22 & 0 & 0 & 90 & 0 & 0 & 0 \\
\hline Lymph node & 0 & 0 & 0 & 0 & 0 & 11 & 0 & 0 & 44 & 11 & 0 & 0 \\
\hline Mammary gland & 26 & 0 & 19 & 26 & 6 & 26 & 72 & 6 & 39 & 33 & 0 & 26 \\
\hline Mouth & 15 & 0 & 30 & 0 & 0 & 60 & 0 & 15 & 15 & 45 & 0 & 30 \\
\hline Muscle & 0 & 0 & 18 & 0 & 0 & 0 & 28 & 0 & 9 & 18 & 9 & 0 \\
\hline Nerve & 64 & 0 & 0 & 64 & 0 & 0 & 0 & 0 & 0 & 128 & 0 & 64 \\
\hline Ovary & 325 & 49 & 9 & 0 & 0 & 29 & 9 & 78 & 39 & 0 & 0 & 29 \\
\hline Pancreas & 32 & 0 & 37 & 4 & 14 & 4 & 32 & 0 & 4 & 14 & 0 & 51 \\
\hline Parathyroid & 0 & 0 & 0 & 0 & 0 & 0 & 0 & 48 & 0 & 48 & 0 & 0 \\
\hline Pharynx & 0 & 0 & 0 & 0 & 0 & 0 & 0 & 0 & 0 & 0 & 0 & 0 \\
\hline Pituitary gland & 0 & 0 & 0 & 0 & 0 & 0 & 0 & 0 & 0 & 0 & 0 & 0 \\
\hline Placenta & 3 & 49 & 88 & 0 & 21 & 63 & 74 & 35 & 67 & 7 & 3 & 52 \\
\hline Prostate & 42 & 0 & 0 & 10 & 5 & 21 & 10 & 15 & 36 & 10 & 0 & 63 \\
\hline Salivary gland & 0 & 0 & 0 & 0 & 0 & 49 & 0 & 0 & 0 & 0 & 0 & 0 \\
\hline Skin & 4 & 0 & 61 & 9 & 0 & 4 & 0 & 0 & 9 & 37 & 0 & 0 \\
\hline Spleen & 37 & 0 & 0 & 0 & 37 & 0 & 0 & 0 & 0 & 0 & 0 & 0 \\
\hline Stomach & 0 & 0 & 62 & 0 & 31 & 125 & 0 & 0 & 10 & 0 & 0 & 10 \\
\hline Testis & 4 & 22 & 0 & 20 & 4 & 6 & 2 & 6 & 34 & 6 & 0 & 4 \\
\hline Thymus & 0 & 0 & 0 & 0 & 0 & 0 & 25 & 0 & 37 & 12 & 0 & 0 \\
\hline Thyroid & 21 & 21 & 0 & 64 & 0 & 0 & 0 & 0 & 0 & 0 & 0 & 0 \\
\hline Tonsil & 0 & 0 & 0 & 0 & 0 & 0 & 0 & 0 & 58 & 58 & 0 & 0 \\
\hline Trachea & 0 & 0 & 0 & 0 & 0 & 0 & 57 & 0 & 19 & 0 & 0 & 0 \\
\hline Umbilical cord & 0 & 0 & 0 & 0 & 0 & 0 & 0 & 72 & 0 & 72 & 0 & 0 \\
\hline Uterus & 4 & 4 & 8 & 4 & 4 & 0 & 17 & 8 & 12 & 17 & 0 & 25 \\
\hline Vascular & 0 & 0 & 290 & 0 & 0 & 19 & 0 & 135 & 0 & 0 & 0 & 0 \\
\hline
\end{tabular}

INHA/BA/BB: Inhibin alpha/beta a/beta b subunit; BMP2/4/5/6/7/11: bone morphogenic protein 2/4/5/6/7/11: TGF $\beta 3$ : transforming growth factor beta 3. Numbers of gene transcripts are transcripts per million that were collected from Unigene (https://www.ncbi.nlm.nih.gov/unigene).

epithelial cell line in vitro (60) and thus might promote prostate cell proliferation by targeting this receptor.

It was found that exogenously added activin A and B induced an inhibitory effect on the growth of two human prostate cancer cell lines, LNCaP and DU145, which was completely reversed by FST (24). Overexpression of FST was observed in human LNCaP cells (81), which is in line with the theory of FST overproduction favouring the growth of prostate cancer by inhibiting signalling of activin (23). However, another human prostate cancer cell line, PC3, is resistant to the growth-inhibiting effects of activin A. Intriguingly, this phenomenon is further explained by the study of McPherson et al. which showed that only PC3 cells produced the FST288 isoform, while LNCaP and DU145 
Table II. Expression of follistatin (FST) and its target genes in malignancies.

\begin{tabular}{|c|c|c|c|c|c|c|c|c|c|c|c|c|}
\hline Tissue & FST & INHA & INHBA & INHBB & BMP2 & BMP4 & BMP5 & BMP6 & BMP7 & BMP11 & Myostatin & TGF $\beta 3$ \\
\hline Adrenal tumor & $0 \downarrow \downarrow$ & 0 & 0 & $79 \uparrow \uparrow$ & 0 & 0 & 0 & 0 & 0 & $79 \uparrow \uparrow$ & 0 & 0 \\
\hline Bladder carcinoma & 0 & 0 & 0 & 0 & 0 & 0 & 0 & 0 & 0 & 0 & 0 & 0 \\
\hline Breast tumor & $42 \uparrow \uparrow$ & 0 & 21 & $32 \uparrow$ & $0 \downarrow \downarrow$ & $42 \uparrow \uparrow$ & $118 \uparrow \uparrow$ & $0 \downarrow \downarrow$ & 42 & $53 \uparrow \uparrow$ & 0 & $42 \uparrow \uparrow$ \\
\hline Cervical tumor & 0 & 0 & 0 & 0 & $347 \uparrow \uparrow$ & 0 & 0 & $86 \uparrow$ & 0 & 0 & 0 & 0 \\
\hline Chondrosarcoma & 132 & 0 & 48 & 0 & 24 & 48 & 0 & 12 & 12 & 72 & 0 & 48 \\
\hline Colorectal tumor & $0 \downarrow \downarrow$ & 0 & 17 & 8 & 17 & 328 & 0 & 26 & 35 & 26 & 0 & 8 \\
\hline Esophageal tumor & 0 & 0 & 57 & 0 & 0 & 0 & 0 & 0 & 0 & 0 & 0 & 57 \\
\hline Gastrointestinal tumor & $25 \uparrow \uparrow$ & 0 & $25 \downarrow \downarrow$ & 0 & $16 \downarrow \downarrow$ & $202 \uparrow \uparrow$ & 0 & 0 & $8 \downarrow$ & 0 & 0 & $8 \downarrow$ \\
\hline Germ cell tumor & 37 & 26 & 0 & 11 & 0 & 7 & 7 & 18 & 91 & 41 & 0 & 3 \\
\hline Glioma & 9 & 0 & 0 & 0 & 46 & 9 & 0 & 0 & 74 & 46 & 0 & 0 \\
\hline Head and neck tumor & 29 & 7 & 29 & 14 & 74 & 37 & 0 & 14 & 7 & 22 & 0 & 7 \\
\hline Kidney tumor & 14 & 0 & $0 \downarrow \downarrow$ & $0 \downarrow \downarrow$ & $0 \downarrow \downarrow$ & $0 \downarrow \downarrow$ & 0 & $0 \downarrow \downarrow$ & $87 \uparrow \uparrow$ & $14 \uparrow \uparrow$ & 0 & $14 \downarrow$ \\
\hline Leukemia & $21 \uparrow$ & 0 & 0 & 0 & 10 & 0 & 0 & 116 & 0 & 21 & 0 & 10 \\
\hline Liver tumor & 20 & 10 & 10 & 10 & 10 & 104 & 0 & 0 & 0 & 31 & 0 & 0 \\
\hline Lung tumor & $68 \uparrow \uparrow$ & $0 \downarrow \downarrow$ & $0 \downarrow \downarrow$ & $0 \downarrow \downarrow$ & $0 \downarrow \downarrow$ & $19 \uparrow$ & $0 \downarrow \downarrow$ & $0 \downarrow \downarrow$ & $0 \downarrow \downarrow$ & $19 \uparrow$ & $0 \downarrow \downarrow$ & $9 \downarrow \downarrow$ \\
\hline Lymphoma & 0 & 0 & 0 & 0 & 0 & 27 & 0 & 0 & 207 & 0 & 0 & 0 \\
\hline Non-neoplasia & 10 & 0 & 31 & 0 & 0 & 10 & 0 & 10 & 31 & 0 & 0 & 0 \\
\hline Normal & 22 & 12 & 24 & 6 & 14 & 21 & 19 & 11 & 33 & 21 & 2 & 26 \\
\hline Ovarian tumor & $393 \uparrow$ & $13 \downarrow \downarrow$ & $0 \downarrow \downarrow$ & 0 & 0 & $39 \uparrow$ & $13 \uparrow$ & $91 \uparrow$ & $52 \uparrow$ & 0 & 0 & $13 \downarrow \downarrow$ \\
\hline Pancreatic tumor & $66 \uparrow \uparrow$ & 0 & $76 \uparrow \uparrow$ & $9 \uparrow \uparrow$ & $0 \downarrow \downarrow$ & $9 \uparrow \uparrow$ & 19 & 0 & $9 \uparrow \uparrow$ & $9 \downarrow \downarrow$ & 0 & $47 \downarrow$ \\
\hline $\begin{array}{l}\text { Primitive neuro- } \\
\text { ectodermal tumor }\end{array}$ & 0 & 7 & 0 & 0 & 0 & 31 & 0 & 0 & 70 & 0 & 0 & 0 \\
\hline Prostate cancer & $48 \uparrow$ & 0 & 0 & $0 \downarrow \downarrow$ & $0 \downarrow \downarrow$ & $28 \uparrow$ & 0 & $19 \uparrow$ & $0 \downarrow \downarrow$ & $19 \uparrow \uparrow$ & 0 & $28 \downarrow \downarrow$ \\
\hline Retinoblastoma & 0 & 0 & 0 & 43 & 0 & 0 & 0 & 0 & 0 & 64 & 0 & 0 \\
\hline Skin tumor & 0 & 0 & 55 & 0 & 0 & 0 & 0 & 0 & 15 & 23 & 0 & 0 \\
\hline Soft tissue/muscle & & & & & & & & & & & & \\
\hline tissue tumor & 31 & 0 & 7 & 0 & 7 & 0 & 39 & 0 & 39 & 23 & 15 & 0 \\
\hline Uterine tumor & $11 \uparrow \uparrow$ & $0 \downarrow \downarrow$ & $22 \uparrow \uparrow$ & $11 \uparrow \uparrow$ & $0 \downarrow \downarrow$ & 0 & $0 \downarrow \downarrow$ & $0 \downarrow \downarrow$ & $33 \uparrow \uparrow$ & $33 \uparrow \uparrow$ & 0 & $22 \downarrow$ \\
\hline
\end{tabular}

INHA/BA/BB: Inhibin alpha/beta a/beta b subunit; BMP2/4/5/6/7/11: bone morphogenic protein 2/4/5/6/7/11; TGF $\beta 3$ : transforming growth factor beta 3. Note: In comparison with corresponding normal control, $\uparrow \uparrow$ represents an increase greater than 50\%, while $\uparrow$ stands for a difference of less than $50 \% ; \downarrow \downarrow$ represents a decrease greater than $50 \%$, while $\downarrow$ stands for a reduction of less than $50 \%$. Numbers of gene transcripts are transcripts per million which were collected from Unigene (https://www.ncbi.nlm.nih.gov/unigene).

cells predominantly produced the FST315 isoform. Blockade of FST288 activity with a neutralizing antibody rendered PC3 cells responsive to activin A, as measured by inhibition of proliferation (25). These results indicate that the resistance of PC 3 cells to activin A is more likely due to predominantly expressed of FST288 in comparison with LNCaP and DU145 cells. Sidis et al. found that inhibition of endogenous activin bioactivity, irrespective of the FST isoforms being administered endogenously or exogenously, was correlated closely with its surface-binding activity (36). These findings suggest that the cell-surface dwelling FST288 isoform inhibits activin-mediated downstream signal transduction pathways more efficiently than the FST315 isoform. Further investigations will shed light on the interaction of the FST288 isoform with activin receptors and, consequently, the biological effects induced by these molecules.

In some cases, however, FST may also inhibit tumour growth. An in vitro study showed that the growth of inhibindeficient gonadal tumour cells from mice could be stimulated in culture via an autocrine mechanism of activin, while FST added to the culture medium slowed the growth rate of the tumour cells (82). Another in vitro study observed that for four ovarian cell lines not synthesizing FST, treatment with activin $(1-100 \mathrm{ng} / \mathrm{ml})$ resulted in an increase of proliferation, whereas FST treatment $(1-100 \mathrm{ng} / \mathrm{ml})$ inhibited their proliferation (83). This inhibitory function was further verified in an in vivo study, showing inhibin-deficient mice that carry the mouse metallothionein I follistatin transgene exhibited a less severe activin-mediated cancer cachexia-like wasting syndrome, lower serum activin levels, and a statistically significant prolonged survival in a number of cases compared with the mice deficient in inhibin alone (51).

\section{Follistatin in Tumour-associated Angiogenesis}

The effect of FST on tumour angiogenesis was found in a study by Ogino et al. (84), in which two human small cell lung cancer cell lines, SBC-3 and SBC-5, were transfected with the 
FST gene and subsequently inoculated into the natural killer cell-depleted severe combined immunodeficient (SCID) mice. Histological analysis results revealed that the number of proliferating tumour cells and the tumour-associated microvessel density were significantly reduced in the lesions produced by FST transfectants, compared with the parental SBC-5 or mock control, which was consistent with the results seen in liver-metastatic lesions produced by FST transfectants. These observations in both lung- and liver-derived tumours is suggestive of FST inhibiting tumour angiogenesis. However, no obvious effect on cell proliferation, motility, invasion, or adhesion were observed for FST in endothelial cells in vitro nor on tumour growth and metastasis in vivo (84).

Unlike the findings by Ogino et al. (84), there is also some evidence indicating that FST may play a promotory role in the progression of tumour angiogenesis. Kozian et al. found that FST implantation in the cornea in combination with subcritical concentrations of fibroblast growth factor (bFGF) induced a strong angiogenic response (85), which demonstrates that FST by itself, but particularly in synergy with bFGF, induces angiogenesis. This may be primarily due to the action of FST antagonising activin, which inhibits bFGF-induced sprouting angiogenesis in vitro and in vivo (40). Other evidence that FST may have a promotory effect on tumour angiogenesis is the study by Krneta et al. in which SCID mice were inoculated with R30C mammary carcinoma cells transfected with FST288 or activin. The FST-expressing tumours had a denser network of small-diameter capillaries than activin-expressing tumours (40). FST288 may be required for the promotion of angiogenesis in a mouse model (49). Collectively, FST, especially the FST288 isoform, seems to be involved in tumour angiogenesis, at least partially through attenuating activin signalling.

\section{Follistatin in Solid Tumour Metastasis}

In the study by Ogino et al., FST transfectants produced significantly fewer metastatic colonies in multiple organs, including lung, liver, and bone in natural killer cell-depleted SCID mice when compared with their parental cells or vector control clones (84), supporting the potential role of FST in controlling tumour metastasis.

BMP2, -4 and -7 , together with their inhibitors, including FST, have been shown to be involved in osteoblastogenesis (86-88). The activin/FST system was reported to play a regulatory role in normal bone homeostasis (89-92). It has been speculated that FST might play a role in the pathogenesis of bone metastasis through interaction with BMPs and activin.

A study demonstrated that ribozyme transgene targeting BMP7 expression in the PC3 prostate cancer cell line resulted in increased invasiveness and motility, which appeared to be facilitated by changes in the level of the BMP antagonists noggin and FST (58). Although these findings indicate the role of FST in solid tumours, more evidence is needed for greater clarification of its involvement in the metastases associated with solid tumours.

\section{Value of Follistatin in Diagnosis, Prognosis and of Solid Tumours}

FST is expressed in multiple tissues $(10,77,93-97)$, and its expression levels are altered in tumour tissues $(25,90,98$ 100) and in body fluids (101-104) of patients with solid tumors. These findings provoked studies investigating FST as a diagnostic or prognostic marker for solid tumours. One study showed that serum FST and ovarian carcinoma antigen CA125 levels were significantly increased in patients with ovarian cancer when compared with healthy individuals and patients with benign ovarian cysts, which suggests that the serum FST level has potential diagnostic value, especially when combined with CA125 detection in order to reduce the number of false-positive results (105). Serum levels of FST were also found to be elevated in patients with hepatocellular cancer (HCC) (21, 106). Survival of patients with HCC with high FST levels was significantly shorter than for those with low serum levels of FST (106). Multivariate analysis revealed that in addition to large tumour size and presence of portal vein thrombus, high FST levels were independently correlated with poor prognosis (106). Therefore, a promising potential is indicated for FST in HCC prognosis. A survival analysis of FST in breast, lung, ovarian and gastric cancer was also performed using an online Kaplan-Meier analysis (http://kmplot.com/analysis/) (Figure 1) (107). An increased expression of FST was associated with poorer overall survival of patients with ovarian, gastric and lung cancer. These data also correlate with the previously mentioned studies of serum level in ovarian cancer and HCC. In contrast, a reduced expression of FST was correlated with shorter relapse-free survival (Figure 1B), although no correlation was seen between FST expression and overall survival of patients with breast cancer (data not shown).

Blank et al. reported FST in serum was negatively correlated and was decreased in both distant and lymph node metastasis associated with gastric cancer compared to patients without metastasis. In contrast, they noted that tissue from the patients with metastasis exhibited higher FST levels. Additionally, neoadjuvantly treated patients with lymph node metastasis still exhibited lower FST levels, whilst those with distant metastasis and poorly differentiated tumors (G3/4) exhibited elevated FST serum levels. Prognostically, a tumour tissue level of FST below the median was associated with better survival. However, in primary resected and neoadjuvantly treated patients, FST levels in tissue had no impact (108). Therefore FST levels appear to have a further prognostic significance in gastric cancer. 

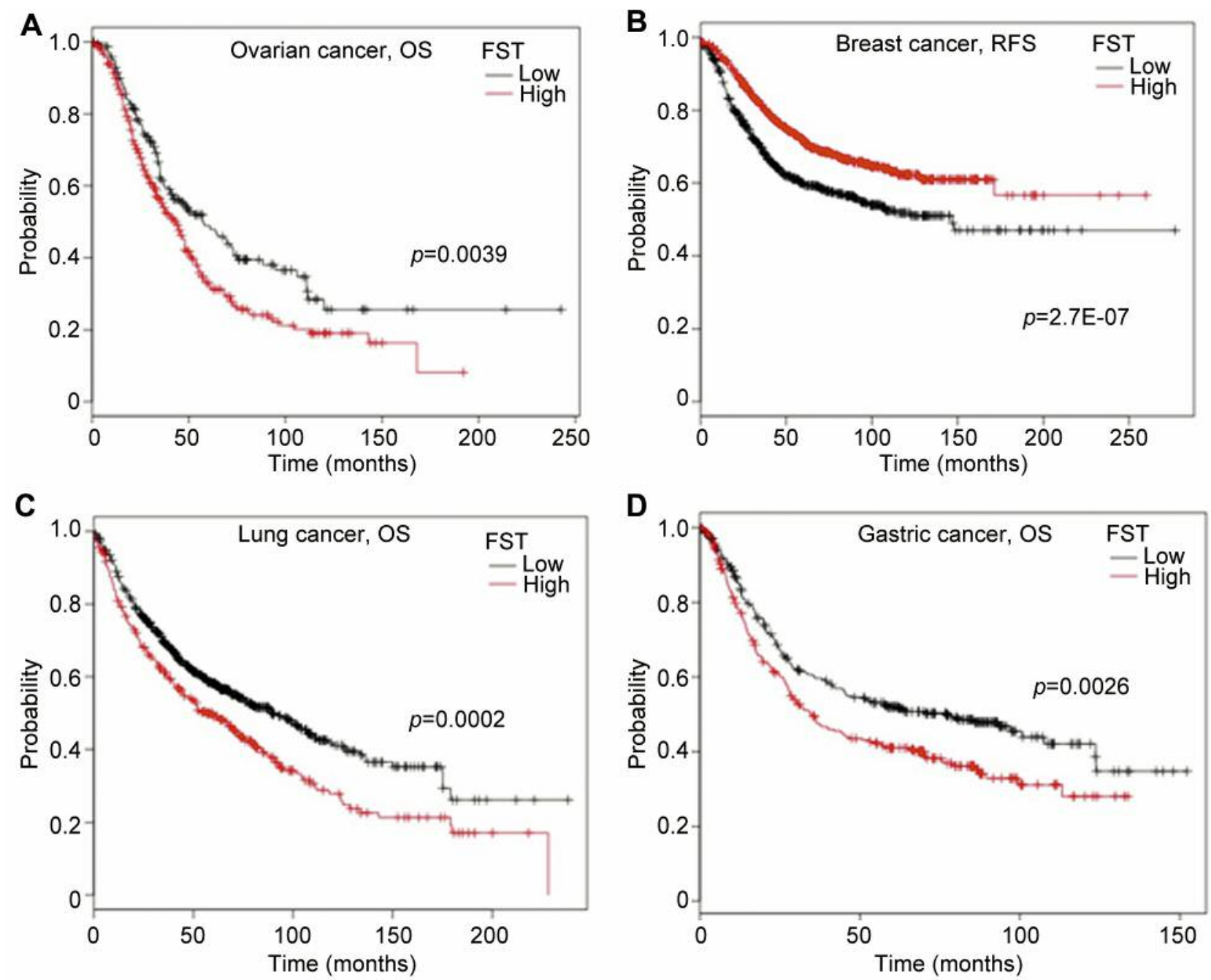

Figure 1. Expression of follistatin (FST) is associated with survival of patients with cancer. The association with survival of patients with ovarian, breast, lung and gastric cancer was analyzed in a combined cohort of these cancer types using an online Kaplan-Meier survival analysis tool (KMplot, http://kmplot.com/analysis/) (107). A: High expression of FST was found to be associated with shorter overall survival (OS) of patients with ovarian cancer. B: High FST expression was associated with relapse-free survival (RFS) of patients with breast cancer. C: High expression of FST was associated with shorter OS of patients with lung cancer. D: High FST expression was associated with shorter OS of patients with gastric cancer. Number of patients of each cohort are provided in Table III. The cut-off levels were auto-selected using the KMplot and number of patients in each group are listed in Table III.

Table III. Number of patients and cut-off levels of follistatin (FST) for the Kaplan-Meier survival analyses.

\begin{tabular}{lccc}
\hline Cancer type (survival) & $\begin{array}{c}\text { Low FST expression } \\
\text { (no. of patients) }\end{array}$ & $\begin{array}{c}\text { High FST expression } \\
\text { (no. of patients) }\end{array}$ & $\begin{array}{c}\text { Cut-off level } \\
\text { (normalised FST expression level) }\end{array}$ \\
\hline Ovarian (OS) & 222 & 358 & 101 \\
Breast (RFS) & 792 & 868 & 238 \\
Lung (OS) & 829 & 316 & 456 \\
Gastric (OS) & 346 & 285 & 94 \\
\hline
\end{tabular}

OS: Overall survival; RFS: relapse-free survival. The association with survival of patients with ovarian, breast, lung and gastric cancer was analysed in a combined cohort of these cancer types using an online Kaplan-Meier survival analysis tool (KMplot, http://kmplot.com/analysis/) (107). Numbers of patients of each cohort and the cut-off levels which were auto-selected using the KMplot are shown. 
Other than the potential from diagnostic and prognostic perspectives, FST might also be considered as a therapeutic target. Grusch et al. reported that FST was overexpressed while both activin subunits were down-regulated in the majority of rat and human liver tumours studied (109). Treatment of normal and pre-neoplastic hepatocytes with FST stimulated DNA synthesis preferentially in preneoplastic rat hepatocytes, whereas activin A repressed it. This study suggests that the balanced expression of FST and activin becomes deregulated during hepatocarcinogenesis and the sensitivity of pre-neoplastichepatocytes to activin signals suggests the activin/FST system might be a promising target for therapeutic intervention.

FST was indicated to have potential in clinical use (81, 104) in prostate cancer, but its diagnostic effectiveness was found not to be significantly superior to that of activin A or prostate-specific antigen (110), although it could still be useful as a biomarker for follow-up of patients with prostate cancer undergoing antimetastatic treatments. Together with another possibility that FST may contribute to fostering bone metastasis formation in patients with prostate cancer $(58,86$ $88,111)$, FST may be regarded as a potential, molecular target in the treatment of metastatic bone disease.

\section{Conclusion}

Based on current findings, FST plays a role in tumourigenesis, progression, metastasis and angiogenesis of solid tumours. This molecule seems to exert its effect mainly by interaction with TGF $\beta$ family members, such as activin and BMPs. As an antagonist of activin, FST seems primarily to function depending on the role that activin plays, exerting context-dependent and cell type-specific inhibition and activation (40), including a stimulating effect observed in activion of the FST-stimulating effect on gastric $(63,112)$ and prostate $(23-25,36,81)$ cancer, while playing an inhibitory role in gonadal tumours $(81,82)$. FST288 has more inhibitory effects on activin-induced biological action than FST315, which has been supported by a series of studies (23-25, 36, $81)$. Future investigations can elucidate the exact role played by the FST288 isoform in solid tumours and also the corresponding application in diagnosis and treatment.

\section{Acknowledgements}

The Authors wish to thank Cancer Research Wales, Welsh Life Science Network (NRN, Ser Cymru) and the Wales Metastasis Platform for their support. Dr Shi was a recipient of the China Medical Scholarship from Cardiff University.

\section{References}

1 Robertson DM, Klein R, de Vos FL, McLachlan RI, Wettenhall RE, Hearn MT, Burger HG and de Kretser DM: The isolation of polypeptides with FSH suppressing activity from bovine follicular fluid which are structurally different to inhibin. Biochem Biophys Res Commun 149: 744-749, 1987.

2 Ueno N, Ling N, Ying SY, Esch F, Shimasaki S and Guillemin $\mathrm{R}$ : Isolation and partial characterization of follistatin: A singlechain $\mathrm{mr}$ 35,000 monomeric protein that inhibits the release of follicle-stimulating hormone. Proc Natl Acad Sci USA 84: 8282-8286, 1987.

3 Sepporta MV, Tumminello FM, Flandina C, Crescimanno M, Giammanco M, La Guardia M, di Majo D and Leto G: Follistatin as potential therapeutic target in prostate cancer. Target Oncol 8: 215-223, 2013.

4 Glister C, Kemp CF and Knight PG: Bone morphogenetic protein (BMP) ligands and receptors in bovine ovarian follicle cells: Actions of BMP-4, -6 and -7 on granulosa cells and differential modulation of SMAD-1 phosphorylation by follistatin. Reproduction 127: 239-254, 2004.

5 Sugino H, Sugino K, Hashimoto O, Shoji H and Nakamura T: Follistatin and its role as an activin-binding protein. J Med Invest 44: 1-14, 1997.

6 Sugino K, Kurosawa N, Nakamura T, Takio K, Shimasaki S, Ling N, Titani K and Sugino H: Molecular heterogeneity of follistatin, an activin-binding protein. Higher affinity of the carboxyl-terminal truncated forms for heparan sulfate proteoglycans on the ovarian granulosa cell. J Biol Chem 268: 15579-15587, 1993.

7 Phillips DJ and de Kretser DM: Follistatin: A multifunctional regulatory protein. Front Neuroendocrinol 19: 287-322, 1998.

8 Schneyer AL, Wang Q, Sidis Y and Sluss PM: Differential distribution of follistatin isoforms: Application of a new FS315specific immunoassay. J Clin Endocrinol Metab 89: 5067-5075, 2004.

9 Thompson TB, Lerch TF, Cook RW, Woodruff TK and Jardetzky TS: The structure of the follistatin:Activin complex reveals antagonism of both type I and type II receptor binding. Dev Cell 9: 535-543, 2005.

10 Michel U, Albiston A and Findlay JK: Rat follistatin: Gonadal and extragonadal expression and evidence for alternative splicing. Biochem Biophys Res Commun 173: 401-407, 1990.

11 Schneyer AL, Hall HA, Lambert-Messerlian G, Wang QF, Sluss $\mathrm{P}$ and Crowley WF Jr.: Follistatin-activin complexes in human serum and follicular fluid differ immunologically and biochemically. Endocrinology 137: 240-247, 1996.

12 Bartholin L, Maguer-Satta V, Hayette S, Martel S, Gadoux M, Corbo L, Magaud JP and Rimokh R: Transcription activation of FLRG and follistatin by activin A, through Smad proteins, participates in a negative feedback loop to modulate activin A function. Oncogene 21: 2227-2235, 2002.

13 Blount AL, Schmidt K, Justice NJ, Vale WW, Fischer WH and Bilezikjian LM: Foxl2 and Smad3 coordinately regulate follistatin gene transcription. J Biol Chem 284: 7631-7645, 2009.

14 Winters SJ, Ghooray D, Fujii Y, Moore JP Jr., Nevitt JR and Kakar SS: Transcriptional regulation of follistatin expression by GnRH in mouse gonadotroph cell lines: Evidence for a role for cAMP signaling. Mol Cell Endocrinol 271: 45-54, 2007.

15 Eichberger T, Kaser A, Pixner C, Schmid C, Klingler S, Winklmayr M, Hauser-Kronberger C, Aberger F and Frischauf AM: GLI2-specific transcriptional activation of the bone morphogenetic protein/activin antagonist follistatin in human epidermal cells. J Biol Chem 283: 12426-12437, 2008. 
16 Hayashi K, Yamaguchi T, Yano S, Kanazawa I, Yamauchi M, Yamamoto $\mathrm{M}$ and Sugimoto T: BMP/Wnt antagonists are upregulated by dexamethasone in osteoblasts and reversed by alendronate and PTH: potential therapeutic targets for glucocorticoid-induced osteoporosis. Biochem Biophys Res Commun 379: 261-266, 2009.

17 Singh R, Bhasin S, Braga M, Artaza JN, Pervin S, Taylor WE, Krishnan V, Sinha SK, Rajavashisth TB and Jasuja R: Regulation of myogenic differentiation by androgens: Cross talk between androgen receptor/beta-catenin and follistatin/ transforming growth factor-beta signaling pathways. Endocrinology 150: 1259-1268, 2009.

18 Willert J, Epping M, Pollack JR, Brown PO and Nusse R: A transcriptional response to Wnt protein in human embryonic carcinoma cells. BMC Dev Biol 2: 8, 2002.

19 Yao HH, Matzuk MM, Jorgez CJ, Menke DB, Page DC, Swain A and Capel B: Follistatin operates downstream of Wnt4 in mammalian ovary organogenesis. Dev Dyn 230: 210-215, 2004.

20 Necela BM, Su W and Thompson EA: Peroxisome proliferatoractivated receptor gamma down-regulates follistatin in intestinal epithelial cells through SP1. J Biol Chem 283: 29784-29794, 2008.

21 Garcia LA, King KK, Ferrini MG, Norris KC and Artaza JN: $1,25(\mathrm{OH}) 2$ vitamin D3 stimulates myogenic differentiation by inhibiting cell proliferation and modulating the expression of promyogenic growth factors and myostatin in $\mathrm{C} 2 \mathrm{C} 12$ skeletal muscle cells. Endocrinology 152: 2976-2986, 2011.

22 Ruspita I, Miyoshi K, Muto T, Abe K, Horiguchi T and Noma $\mathrm{T}$ : Sp6 downregulation of follistatin gene expression in ameloblasts. J Med Invest 55: 87-98, 2008.

23 Thomas TZ, Wang H, Niclasen P, O'Bryan MK, Evans LW, Groome NP, Pedersen J and Risbridger GP: Expression and localization of activin subunits and follistatins in tissues from men with high grade prostate cancer. J Clin Endocrinol Metab 82: 3851-3858, 1997.

24 van Schaik RH, Wierikx CD, Timmerman MA, Oomen MH, van Weerden WM, van der Kwast TH, van Steenbrugge GJ and de Jong FH: Variations in activin receptor, inhibin/activin subunit and follistatin mRNAs in human prostate tumour tissues. Br J Cancer 82: 112-117, 2000.

25 McPherson SJ, Mellor SL, Wang H, Evans LW, Groome NP and Risbridger GP: Expression of activin A and follistatin core proteins by human prostate tumor cell lines. Endocrinology 140: 5303-5309, 1999.

26 Sulyok S, Wankell M, Alzheimer C and Werner S: Activin: An important regulator of wound repair, fibrosis, and neuroprotection. Mol Cell Endocrinol 225: 127-132, 2004.

27 Welt CK: The physiology and pathophysiology of inhibin, activin and follistatin in female reproduction. Curr Opin Obstet Gynecol 14: 317-323, 2002.

28 Abe Y, Minegishi T and Leung PC: Activin receptor signaling. Growth Factors 22: 105-110, 2004.

29 Knight PG: Roles of inhibins, activins, and follistatin in the female reproductive system. Front Neuroendocrinol 17: 476509, 1996.

30 DePaolo LV: Inhibins, activins, and follistatins: The saga continues. Proc Soc Exp Biol Med 214: 328-339, 1997.

31 Nakamura T, Sugino K, Titani K and Sugino H: Follistatin, an activin-binding protein, associates with heparan sulfate chains of proteoglycans on follicular granulosa cells. J Biol Chem 266: 19432-19437, 1991.
32 Hashimoto O, Kawasaki N, Tsuchida K, Shimasaki S, Hayakawa $\mathrm{T}$ and Sugino $\mathrm{H}$ : Difference between follistatin isoforms in the inhibition of activin signalling: Activin neutralizing activity of follistatin isoforms is dependent on their affinity for activin. Cell Signal 12: 565-571, 2000.

33 Hashimoto O, Nakamura T, Shoji H, Shimasaki S, Hayashi Y and Sugino $\mathrm{H}$ : A novel role of follistatin, an activin-binding protein, in the inhibition of activin action in rat pituitary cells. Endocytotic degradation of activin and its acceleration by follistatin associated with cell-surface heparan sulfate. J Biol Chem 272: 13835-13842, 1997.

34 Harrington AE, Morris-Triggs SA, Ruotolo BT, Robinson CV, Ohnuma $S$ and Hyvonen M: Structural basis for the inhibition of activin signalling by follistatin. EMBO J 25: 1035-1045, 2006.

35 Lerch TF, Shimasaki S, Woodruff TK and Jardetzky TS: Structural and biophysical coupling of heparin and activin binding to follistatin isoform functions. J Biol Chem 282: 15930-15939, 2007.

36 Sidis Y, Mukherjee A, Keutmann H, Delbaere A, Sadatsuki M and Schneyer A: Biological activity of follistatin isoforms and follistatin-like-3 is dependent on differential cell surface binding and specificity for activin, myostatin, and bone morphogenetic proteins. Endocrinology 147: 3586-3597, 2006.

37 Nakamura T, Takio K, Eto Y, Shibai H, Titani K and Sugino H: Activin-binding protein from rat ovary is follistatin. Science 247: 836-838, 1990.

38 Keutmann HT, Schneyer AL and Sidis Y: The role of follistatin domains in follistatin biological action. Mol Endocrinol 18: 228-240, 2004.

39 Innis CA and Hyvonen M: Crystal structures of the heparan sulfate-binding domain of follistatin. Insights into ligand binding. J Biol Chem 278: 39969-39977, 2003.

40 Krneta J, Kroll J, Alves F, Prahst C, Sananbenesi F, Dullin C, Kimmina S, Phillips DJ and Augustin HG: Dissociation of angiogenesis and tumorigenesis in follistatin- and activinexpressing tumors. Cancer Res 66: 5686-5695, 2006.

41 Erlebacher A, Price KA and Glimcher LH: Maintenance of mouse trophoblast stem cell proliferation by TGF-beta/activin. Dev Biol 275: 158-169, 2004.

42 Ota F, Maeshima A, Yamashita S, Ikeuchi H, Kaneko Y, Kuroiwa T, Hiromura K, Ueki K, Kojima I and Nojima Y: Activin a induces cell proliferation of fibroblast-like synoviocytes in rheumatoid arthritis. Arthritis Rheum 48: 24422449, 2003.

43 Cho SH, Yao Z, Wang SW, Alban RF, Barbers RG, French SW and Oh CK: Regulation of activin A expression in mast cells and asthma: Its effect on the proliferation of human airway smooth muscle cells. J Immunol 170: 4045-4052, 2003.

44 Hedger MP, Phillips DJ and de Kretser DM: Divergent cellspecific effects of activin-A on thymocyte proliferation stimulated by phytohemagglutinin, and interleukin 1beta or interleukin 6 in vitro. Cytokine 12: 595-602, 2000.

45 Martins da Silva SJ, Bayne RA, Cambray N, Hartley PS, McNeilly AS and Anderson RA: Expression of activin subunits and receptors in the developing human ovary: Activin a promotes germ cell survival and proliferation before primordial follicle formation. Dev Biol 266: 334-345, 2004.

46 Sakurai T, Abe Y, Kasuya Y, Takuwa N, Shiba R, Yamashita T, Endo $\mathrm{T}$ and Goto K: Activin A stimulates mitogenesis in Swiss 
3T3 fibroblasts without activation of mitogen-activated protein kinases. J Biol Chem 269: 14118-14122, 1994.

47 Hashimoto M, Shoda A, Inoue S, Yamada R, Kondo T, Sakurai $\mathrm{T}$, Ueno $\mathrm{N}$ and Muramatsu $\mathrm{M}$ : Functional regulation of osteoblastic cells by the interaction of activin-A with follistatin. J Biol Chem 267: 4999-5004, 1992.

48 Matzuk MM, Kumar TR, Vassalli A, Bickenbach JR, Roop DR, Jaenisch R and Bradley A: Functional analysis of activins during mammalian development. Nature 374: 354-356, 1995.

49 Lin SY, Craythorn RG, O'Connor AE, Matzuk MM, Girling JE, Morrison JR and de Kretser DM: Female infertility and disrupted angiogenesis are actions of specific follistatin isoforms. Mol Endocrinol 22: 415-429, 2008.

50 Guo Q, Kumar TR, Woodruff T, Hadsell LA, DeMayo FJ and Matzuk MM: Overexpression of mouse follistatin causes reproductive defects in transgenic mice. Mol Endocrinol 12: 96106, 1998.

51 Cipriano SC, Chen L, Kumar TR and Matzuk MM: Follistatin is a modulator of gonadal tumor progression and the activininduced wasting syndrome in inhibin-deficient mice. Endocrinology 141: 2319-2327, 2000.

52 Kingsley DM, Bland AE, Grubber JM, Marker PC, Russell LB, Copeland NG and Jenkins NA: The mouse short ear skeletal morphogenesis locus is associated with defects in a bone morphogenetic member of the TGF beta superfamily. Cell 71: 399-410, 1992.

53 Sellheyer K, Bickenbach JR, Rothnagel JA, Bundman D, Longley MA, Krieg T, Roche NS, Roberts AB and Roop DR: Inhibition of skin development by overexpression of transforming growth factor beta 1 in the epidermis of transgenic mice. Proc Natl Acad Sci USA 90: 5237-5241, 1993.

54 Iemura S, Yamamoto TS, Takagi C, Uchiyama H, Natsume T, Shimasaki S, Sugino H and Ueno N: Direct binding of follistatin to a complex of bone-morphogenetic protein and its receptor inhibits ventral and epidermal cell fates in early xenopus embryo. Proc Natl Acad Sci USA 95: 9337-9342, 1998.

55 Amthor H, Christ B, Rashid-Doubell F, Kemp CF, Lang E and Patel K: Follistatin regulates bone morphogenetic protein-7 (BMP-7) activity to stimulate embryonic muscle growth. Dev Biol 243: 115-127, 2002.

56 McConnell DS, Wang Q, Sluss PM, Bolf N, Khoury RH, Schneyer AL, Midgley AR Jr., Reame NE, Crowley WF, Jr. and Padmanabhan V: A two-site chemiluminescent assay for activin-free follistatin reveals that most follistatin circulating in men and normal cycling women is in an activin-bound state. $\mathbf{J}$ Clin Endocrinol Metab 83: 851-858, 1998.

57 Havard M, Dautry F and Tchenio T: A dormant state modulated by osmotic pressure controls clonogenicity of prostate cancer cells. J Biol Chem 286: 44177-44186, 2011.

58 Ye L, Lewis-Russell JM, Kynaston $\mathrm{H}$ and Jiang WG: Endogenous bone morphogenetic protein-7 controls the motility of prostate cancer cells through regulation of bone morphogenetic protein antagonists. J Urol 178: 1086-1091, 2007.

59 Amthor H, Nicholas G, McKinnell I, Kemp CF, Sharma M, Kambadur R and Patel K: Follistatin complexes myostatin and antagonises myostatin-mediated inhibition of myogenesis. Dev Biol 270: 19-30, 2004.

60 Nogai H, Rosowski M, Grun J, Rietz A, Debus N, Schmidt G, Lauster C, Janitz M, Vortkamp A and Lauster R: Follistatin antagonizes transforming growth factor-beta3-induced epithelial-mesenchymal transition in vitro: Implications for murine palatal development supported by microarray analysis. Differentiation 76: 404-416, 2008.

$61 \mathrm{Gao} \mathrm{X}$, $\mathrm{Hu} \mathrm{H}$, Zhu $\mathrm{J}$ and $\mathrm{Xu} \mathrm{Z}$ : Identification and characterization of follistatin as a novel angiogenin-binding protein. FEBS Lett 581: 5505-5510, 2007.

62 Phillips DJ, McFarlane JR, Hearn MT and de Kretser DM: Inhibin, activin and follistatin bind preferentially to the transformed species of alpha 2-macroglobulin. J Endocrinol 155: 65-71, 1997.

63 Kang W, Saqui-Salces M, Zavros Y and Merchant JL: Induction of follistatin precedes gastric transformation in gastrin deficient mice. Biochem Biophys Res Commun 376: 573-577, 2008.

64 Eichberger T, Sander V, Schnidar H, Regl G, Kasper M, Schmid C, Plamberger S, Kaser A, Aberger F and Frischauf AM: Overlapping and distinct transcriptional regulator properties of the GLI1 and GLI2 oncogenes. Genomics 87: 616-632, 2006.

65 Stove C, Vanrobaeys F, Devreese B, Van Beeumen J, Mareel M and Bracke M: Melanoma cells secrete follistatin, an antagonist of activin-mediated growth inhibition. Oncogene 23: 53305339, 2004.

66 Nakamura T, Tomita Y, Hirai R, Yamaoka K, Kaji K and Ichihara A: Inhibitory effect of transforming growth factor-beta on DNA synthesis of adult rat hepatocytes in primary culture. Biochem Biophys Res Commun 133: 1042-1050, 1985.

67 Carr BI, Hayashi I, Branum EL and Moses HL: Inhibition of DNA synthesis in rat hepatocytes by platelet-derived type beta transforming growth factor. Cancer Res 46: 2330-2334, 1986.

68 Oberhammer F, Bursch W, Parzefall W, Breit P, Erber E, Stadler $M$ and Schulte-Hermann R: Effect of transforming growth factor beta on cell death of cultured rat hepatocytes. Cancer Res 51: 2478-2485, 1991.

69 Oberhammer FA, Pavelka M, Sharma S, Tiefenbacher R, Purchio AF, Bursch W and Schulte-Hermann R: Induction of apoptosis in cultured hepatocytes and in regressing liver by transforming growth factor beta 1. Proc Natl Acad Sci USA 89: 5408-5412, 1992.

70 Schwall RH, Robbins K, Jardieu P, Chang L, Lai C and Terrell TG: Activin induces cell death in hepatocytes in vivo and in vitro. Hepatology 18: 347-356, 1993.

71 Yasuda H, Mine T, Shibata H, Eto Y, Hasegawa Y, Takeuchi T, Asano S and Kojima I: Activin A: An autocrine inhibitor of initiation of DNA synthesis in rat hepatocytes. J Clin Invest 92: 1491-1496, 1993.

72 Hully JR, Chang L, Schwall RH, Widmer HR, Terrell TG and Gillett NA: Induction of apoptosis in the murine liver with recombinant human activin a. Hepatology 20: 854-862, 1994.

73 Kogure K, Omata W, Kanzaki M, Zhang YQ, Yasuda H, Mine $\mathrm{T}$ and Kojima I: A single intraportal administration of follistatin accelerates liver regeneration in partially hepatectomized rats. Gastroenterology 108: 1136-1142, 1995.

74 Kogure K, Zhang YQ, Kanzaki M, Omata W, Mine T and Kojima I: Intravenous administration of follistatin: Delivery to the liver and effect on liver regeneration after partial hepatectomy. Hepatology 24: 361-366, 1996.

75 Kogure K, Zhang YQ, Shibata H and Kojima I: Immediate onset of DNA synthesis in remnant rat liver after $90 \%$ hepatectomy by an administration of follistatin. J Hepatol 29: 977-984, 1998. 
76 Kogure K, Zhang YQ, Maeshima A, Suzuki K, Kuwano H and Kojima I: The role of activin and transforming growth factorbeta in the regulation of organ mass in the rat liver. Hepatology 31: 916-921, 2000.

77 Rossmanith W, Chabicovsky M, Grasl-Kraupp B, Peter B, Schausberger E and Schulte-Hermann R: Follistatin overexpression in rodent liver tumors: A possible mechanism to overcome activin growth control. Mol Carcinog 35: 1-5, 2002.

78 van der Poel HG, Hanrahan C, Zhong H and Simons JW: Rapamycin induces smad activity in prostate cancer cell lines. Urol Res 30: 380-386, 2003.

79 Handayani R, Rice L, Cui Y, Medrano TA, Samedi VG, Baker HV, Szabo NJ and Shiverick KT: Soy isoflavones alter expression of genes associated with cancer progression, including interleukin-8, in androgen-independent PC-3 human prostate cancer cells. J Nutr 136: 75-82, 2006.

80 Ajiboye S, Sissung TM, Sharifi N and Figg WD: More than an accessory: Implications of type III transforming growth factorbeta receptor loss in prostate cancer. BJU Int 105: 913-916, 2010.

81 Harkonen P, Torn S, Kurkela R, Porvari K, Pulkka A, Lindfors $\mathrm{A}$, Isomaa $\mathrm{V}$ and Vihko P: Sex hormone metabolism in prostate cancer cells during transition to an androgen-independent state. J Clin Endocrinol Metab 88: 705-712, 2003.

82 Shikone T, Matzuk MM, Perlas E, Finegold MJ, Lewis KA, Vale W, Bradley A and Hsueh AJ: Characterization of gonadal sex cord-stromal tumor cell lines from inhibin-alpha and p53deficient mice: The role of activin as an autocrine growth factor. Mol Endocrinol 8: 983-995, 1994.

83 Di Simone N, Crowley WF Jr., Wang QF, Sluss PM and Schneyer AL: Characterization of inhibin/activin subunit, follistatin, and activin type II receptors in human ovarian cancer cell lines: A potential role in autocrine growth regulation. Endocrinology 137: 486-494, 1996.

84 Ogino H, Yano S, Kakiuchi S, Muguruma H, Ikuta K, Hanibuchi M, Uehara H, Tsuchida K, Sugino H and Sone S: Follistatin suppresses the production of experimental multipleorgan metastasis by small cell lung cancer cells in natural killer cell-depleted SCID mice. Clin Cancer Res 14: 660-667, 2008.

85 Kozian DH, Ziche M and Augustin HG: The activin-binding protein follistatin regulates autocrine endothelial cell activity and induces angiogenesis. Lab Invest 76: 267-276, 1997.

86 Fajardo M, Liu CJ and Egol K: Levels of expression for BMP7 and several BMP antagonists may play an integral role in a fracture nonunion: A pilot study. Clin Orthop Relat Res 467: 3071-3078, 2009.

87 Abe Y, Abe T, Aida Y, Hara Y and Maeda K: Follistatin restricts bone morphogenetic protein (BMP)-2 action on the differentiation of osteoblasts in fetal rat mandibular cells. J Bone Miner Res 19: 1302-1307, 2004.

88 Dudaric L, Cvek SZ, Cvijanovic O, Santic V, Maric I, Crncevic-Orlic Z and Bobinac D: Expression of the BMP-2, -4 and -7 and their antagonists gremlin, chordin, noggin and follistatin during ectopic osteogenesis. Coll Antropol 37: 12911298, 2013.

89 Kawabata N, Kamiya N, Suzuki N, Matsumoto M and Takagi $\mathrm{M}$ : Changes in extracellular activin A:Follistatin ratio during differentiation of a mesenchymal progenitor cell line, ROB-C26 into osteoblasts and adipocytes. Life Sci 81: 8-18, 2007.
90 Eijken M, Swagemakers S, Koedam M, Steenbergen C, Derkx P, Uitterlinden AG, van der Spek PJ, Visser JA, de Jong FH, Pols HA and van Leeuwen JP: The activin A-follistatin system: Potent regulator of human extracellular matrix mineralization. FASEB J 21: 2949-2960, 2007.

91 Gajos-Michniewicz A, Piastowska AW, Russell JA and Ochedalski T: Follistatin as a potent regulator of bone metabolism. Biomarkers 15: 563-574, 2010.

92 Gajos-Michniewicz A, Pawlowska E, Ochedalski $\mathrm{T}$ and Piastowska-Ciesielska A: The influence of follistatin on mechanical properties of bone tissue in growing mice with overexpression of follistatin. J Bone Miner Metab 30: 426-433, 2012.

93 Matzuk MM, Kumar TR, Shou W, Coerver KA, Lau AL, Behringer RR and Finegold MJ: Transgenic models to study the roles of inhibins and activins in reproduction, oncogenesis, and development. Recent Prog Horm Res 51: 123-154; discussion 155-127, 1996.

94 Shimonaka M, Inouye S, Shimasaki S and Ling N: Follistatin binds to both activin and inhibin through the common subunit. Endocrinology 128: 3313-3315, 1991.

95 Shimasaki S, Koga M, Buscaglia ML, Simmons DM, Bicsak TA and Ling N: Follistatin gene expression in the ovary and extragonadal tissues. Mol Endocrinol 3: 651-659, 1989.

96 Albano RM, Arkell R, Beddington RS and Smith JC: Expression of inhibin subunits and follistatin during postimplantation mouse development: Decidual expression of activin and expression of follistatin in primitive streak, somites and hindbrain. Development 120: 803-813, 1994.

97 Michel U, Rao A and Findlay JK: Rat follistatin: Ontogeny of steady-state mrna levels in different tissues predicts organ-specific functions. Biochem Biophys Res Commun 180: 223-230, 1991.

98 Gold E and Risbridger G: Activins and activin antagonists in the prostate and prostate cancer. Mol Cell Endocrinol 359: 107$112,2012$.

99 Thomas TZ, Chapman SM, Hong W, Gurusingfhe C, Mellor SL, Fletcher R, Pedersen $\mathrm{J}$ and Risbridger GP: Inhibins, activins and follistatins: expression of mRNAs and cellular localization in tissues from men with benign prostatic hyperplasia. Prostate 34: 34-43, 1998.

100 Vaarala MH, Porvari K, Kyllonen A and Vihko P: Differentially expressed genes in two LNCaP prostate cancer cell lines reflecting changes during prostate cancer progression. Lab Invest 80: 1259-1268, 2000.

101 Buijs JT, Petersen M, van der Horst G and van der Pluijm G: Bone morphogenetic proteins and its receptors; therapeutic targets in cancer progression and bone metastasis? Curr Pharm Des 16: 1291-1300, 2010.

102 Simon DP, Vadakkadath Meethal S, Wilson AC, Gallego MJ, Weinecke SL, Bruce E, Lyons PF, Haasl RJ, Bowen RL and Atwood CS: Activin receptor signaling regulates prostatic epithelial cell adhesion and viability. Neoplasia 11: 365-376, 2009.

103 Kang Y, Siegel PM, Shu W, Drobnjak M, Kakonen SM, Cordon-Cardo C, Guise TA and Massague J: A multigenic program mediating breast cancer metastasis to bone. Cancer Cell 3: 537-549, 2003.

104 Sardana G, Jung K, Stephan C and Diamandis EP: Proteomic analysis of conditioned media from the PC3, LNCaP and 22Rv1 prostate cancer cell lines: Discovery and validation of candidate prostate cancer biomarkers. J Proteome Res 7: 3329-3338, 2008 . 
105 Ren P, Chen FF, Liu HY, Cui XL, Sun Y, Guan JL, Liu ZH, Liu JG and Wang YN: High serum levels of follistatin in patients with ovarian cancer. J Int Med Res 40: 877-886, 2012.

106 Tomoda T, Nouso K, Miyahara K, Kobayashi S, Kinugasa H, Toyosawa J, Hagihara H, Kuwaki K, Onishi H, Nakamura S, Ikeda F, Miyake Y, Shiraha H, Takaki A and Yamamoto K: Prognotic impact of serum follistatin in patients with hepatocellular carcinoma. J Gastroenterol Hepatol 28: 13911396, 2013.

107 Szasz AM, Lanczky A, Nagy A, Forster S, Hark K, Green JE, Boussioutas A, Busuttil R, Szabo A and Gyorffy B: Crossvalidation of survival associated biomarkers in gastric cancer using transcriptomic data of 1,065 patients. Oncotarget, 2016.

108 Blank S, Deck C, Dreikhausen L, Weichert W, Giese N, Falk $\mathrm{C}$, Schmidt $\mathrm{T}$ and Ott K: Angiogenic and growth factors in gastric cancer. J Surg Res 194: 420-429, 2015.

109 Grusch M, Drucker C, Peter-Vorosmarty B, Erlach N, Lackner A, Losert A, Macheiner D, Schneider WJ, Hermann M, Groome NP, Parzefall W, Berger W, Grasl-Kraupp B and SchulteHermann R: Deregulation of the activin/follistatin system in hepatocarcinogenesis. J Hepatol 45: 673-680, 2006.
110 Tumminello FM, Badalamenti G, Fulfaro F, Incorvaia L, Crescimanno M, Flandina C, Sepporta MV and Leto G: Serum follistatin in patients with prostate cancer metastatic to the bone. Clin Exp Metastasis 27: 549-555, 2010.

111 Muller A, Homey B, Soto H, Ge N, Catron D, Buchanan ME, McClanahan T, Murphy E, Yuan W, Wagner SN, Barrera JL, Mohar A, Verastegui E and Zlotnik A: Involvement of chemokine receptors in breast cancer metastasis. Nature 410 : 50-56, 2001.

112 Kim H, Eun JW, Lee H, Nam SW, Rhee H, Koh KH and Kim $\mathrm{H}$ : Gene expression changes in patient-matched gastric normal mucosa, adenomas, and carcinomas. Exp Mol Pathol 90: 201209, 2011. 